\title{
DEVELOPMENT AND VALIDATION OF A UV SPECTROPHOTOMETRIC METHOD FOR DETERMINATION OF AGOMELATINE IN BULK AND A TABLET DOSAGE FORM
}

\author{
Firake Bhushan M. ${ }^{1 *}$, Pathak Pranjalee V. ${ }^{2}$, Dorik Pallavi K. ${ }^{2}$ and Siddaiah M. ${ }^{3}$ \\ ${ }^{1}$ Faculty of Pharmacy, Bhagwant University, Ajmer, Rajasthan, India. \\ ${ }^{2}$ JSPM's Jayawantaro Sawant College of Pharmacy \& Research, Hadapsar, Pune, Maharashtra, India. \\ ${ }^{3}$ Jawaharlal Nehru Technological University, Anantapur. Andhra Pradesh, India
}

Article Info: Received 23 December 2020; Accepted 30 January 2021

DOI: https://doi.org/10.32553/jbpr.v10i1.828

Corresponding author: Firake Bhushan $\mathrm{M}$.

Conflict of interest statement: No conflict of interest

\begin{abstract}
UV spectrophotometry is an analytical technique used routinely for qualitative and quantitative assay due the low cost and reliability during analysis. An simple, efficient, rapid, sensitive, precise and economical UV Spectrophotometric method has been developed for estimation of agomelatine from bulk and pharmaceutical formulation. The method was developed and validated according to International Conference on Harmonization (ICH Q2 R1) guidelines. The $\lambda_{\max }$ of agomelatine in acetonitrile was found to be $229.6 \mathrm{~nm}$. The analytical method validation parameters linearity, precision, accuracy, robustness were studied according to International Conference on Harmonization guidelines. Pure drug concentration was prepared in the range of $1-10 \mu \mathrm{g} / \mathrm{ml}$ and the linear regression analysis data showed good linear relationship with correlation coefficient value 0.9937 . The precision of the method was studied as an intra- day, inter-day variations with value less than $2 \%$ RSD. The limit of detection and limit of quantitation were found to be 0.577 and $1.248 \mu \mathrm{g} / \mathrm{ml}$, respectively. Recoveries were found to be in the range of 100.815 to $101.744 \%$ and \% RSD was less than $2 \%$. This proposed UV spectroscopic method is simple and suitable for routine analysis.
\end{abstract}

Keywords: Keywords: Agomelatine, Validation, UV Spectrophotometric method

\section{Introduction}

Agomelatine (AGM) is chemically N- [2-(7methoxy napthalen-1-yl) ethyl] acetamide (Fig.1). Its molecular formula is $\mathrm{C}_{15} \mathrm{H}_{17} \mathrm{NO}_{2}$ and its molecular weight is $243.301 \mathrm{gm} / \mathrm{mol}$. AGM is an acetamide naphthalene analogue of melatonin. AGM is a novel melatonergic antidepressant agent. It is a potential and well-tolerated medication for the treatment of major depressive disorder. AGM acts as a melatonergic receptor $\left(\mathrm{MT}_{1} / \mathrm{MT}_{2}\right)$ agonist and serotonergic receptor $\left(5-\mathrm{HT}_{2} \mathrm{C}\right)$ antagonist. AGM works by restoring the balance of the circadian rhythm. AGM has also proven to have anxiolytic properties and thus may prove to be very useful in the treatment of anxiety disorders. Because of its action upon the melatonin receptors, AGM shows a marked improvement on sleep. Bioavailability is less than 5\%. AGM is absorbed quickly in humans after oral administration. The mean half-life of AGM is 2.3 hours. AGM was bound to plasma proteins at $95 \%$ mainly to serum albumin (about 35\%) and alpha1-acid glycoprotein (about 36\%). The metabolism of AGM is almost completely hepatic. An extensive first pass hepatic effect is observed. It is practically insoluble in water and very soluble in organic solvents such as ethanol, methanol and dichloromethane.

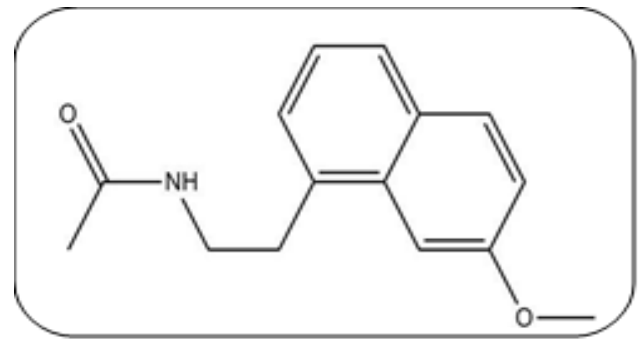

Figure 1: Chemical structure of Agomelatine (AGM) 
The literature reports some analytical assays applied to AGM in different matrices. Among them, we highlighted HPLC chromatographic methods for quantitation in pharmaceuticals ${ }^{4-11}$, LC-MS-MS method $^{12}$. Being an alternative to chromatographic assay, in the present study we aimed to develop an UV spectrophotometric method for quantitative analysis of agomelatine in commercial sample, applying validation protocols.

\section{Materials and Methods}

\section{Instrumentation:}

A double beam Shimadzu UV/Vis spectrophotometer, model 1800 (Japan) having a spectral bandwidth of $1 \mathrm{~nm}$, wavelength accuracy of $\pm 0.5 \mathrm{~nm}$ and a pair of $1 \mathrm{~cm}$ quartz cells was used.

\section{Reagents and Reference substance:}

A generous gift sample of standard AGM was from Sun Pharma Laboratories Ltd, Sikkim (India). The marketed AGM tablets (Agoprex) containing $25 \mathrm{mg}$ of AGM, manufactured by Sun Pharma Laboratories Ltd, Sikkim, (India) were purchased from market. All other chemicals used were of analytical grade.

\section{Standard Preparation:}

Accurately weighed quantity of $25.00 \mathrm{mg}$ of AGM was transferred into $50 \mathrm{ml}$ volumetric flask containing $25 \mathrm{ml}$ acetonitrile. The volume was made up with acetonitrile with a strength of 500 $\mu \mathrm{g} / \mathrm{ml}$ (stock solution).

Further $1 \mathrm{ml}$ of this stock solution was taken in 100 ml volumetric flask and make up to mark with using water. (Final concentration of standard solution obtained was $5 \mu \mathrm{g} / \mathrm{ml}$ ).

\section{Test Preparation:}

Twenty tablets were weighed and powdered. The average weight of tablet was determined. From these, weighed amount of the powder, equivalent to $25 \mathrm{mg}$ of AGM was transferred into the $50 \mathrm{ml}$ volumetric flask. About $25 \mathrm{ml}$ acetonitrile was added and sonicated for a minimum $30 \mathrm{~min}$. with intermittent shaking. Then content was brought back to room temperature and diluted to volume with acetonitrile. The sample was filtered through $0.45 \mu \mathrm{m}$ Whatman filter paper. The concentration obtained was $500 \mu \mathrm{g} / \mathrm{ml}$ of AGM.

Further take $1 \mathrm{ml}$ of this filtrate solution in $100 \mathrm{ml}$ volumetric flask and make up to mark with using water. The concentration obtained was $5 \mu \mathrm{g} / \mathrm{ml}$ of AGM.
Determination of wavelength of maximum absorption:

Determination the $\lambda_{\max }$ for AGM detection using diluents was carried out by UV spectroscopic scanning $(400-200 \mathrm{~nm})$ with the prepared standard solution (Fig. 2).

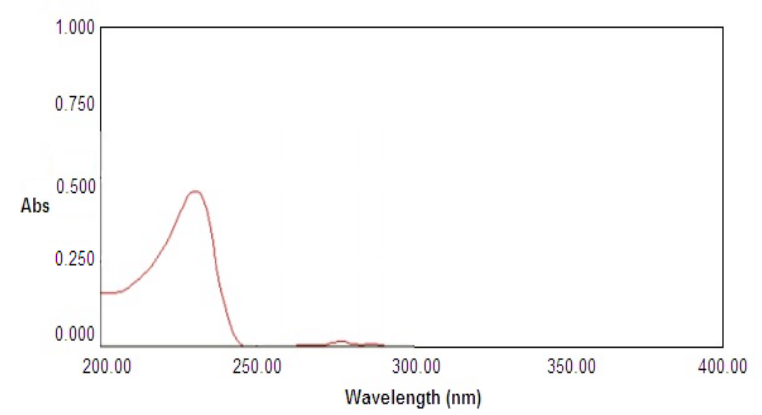

Figure 2: UV spectrum of AGM

\section{Linearity:}

AGM test solutions for the assay method were prepared at analyte concentration $(1,2,3,4,5,6,7$, $8,9$ and $10 \mu \mathrm{g} / \mathrm{ml})$. The linearity of test solutions for the assay method was found to be in the range of 1$10 \mu \mathrm{g} / \mathrm{ml}$ with linear correlation coefficient 0.9937 . Beer-Lambert law was obeyed in the range.

\section{Intra-day precision and Inter-day precision:}

The precision of the assay method was evaluated in terms of repeatability by carrying out six independent assays of agomelatine test sample preparation and calculated the \% RSD of assay (intraday). Intermediate precision of the method was checked by performing same procedure on the different day (inter day) by another person under experimental condition.

\section{Limit of detection (LOD) and limit of quantification (LOQ):}

ICH defines the limit of detection of an analytical method as the lowest amount of analyte in a sample, which can be detected but not necessarily quantitated as an exact value whereas limit of quantitation of an analytical procedure is the lowest amount of analyte in a sample, which can be determined quantitively with suitable precision and accuracy. LOD and LOQ were calculated by using following formula: $\mathrm{LOD}=3.3 \times \sigma / \mathrm{S}$ and $\mathrm{LOQ}=$ $10 \times \sigma / \mathrm{S}$, where, $\sigma$ is the standard deviation of $y$ intercepts of regression line, $\mathrm{S}$ is slope of the calibration curve. 


\section{Accuracy/Recovery:}

Accuracy of the method was checked by the recovery studies at three different levels, i.e., 50, 100 and $150 \%$.

\section{Robustness:}

The study of robustness was carried out to evaluate the influence of slightly changed conditions in the Spectrophotometric method. The factors chosen for this study were the diluents change and analyst change.

\section{Solution stability:}

The stability study of solution for test preparation was carried out. The solution was preserved at ambient temperature and $2-5^{\circ} \mathrm{C}$ and tested at interval of 12, 24, 36 and $48 \mathrm{hr}$. The responses for the aged solution were evaluated using a freshly prepared standard solution.

\section{Results and Discussion}

\section{Method development and Optimization:}

The standard solution of AGM was prepared in acetonitrile during development and optimization phase, as AGM is freely soluble in organic solvents like acetonitrile. And further dilutions were made using distilled water. The $\lambda_{\max }$ in acetonitrile was found to be $229.6 \mathrm{~nm}$.

\section{Method Validation:}

The analytical method was validated as per ICH guidelines.

\section{Linearity:}

A calibration graph was obtained by plotting AGM concentrations against their corresponding absorbance values. Linearity was good in concentration range 1 to $10 \mu \mathrm{g} / \mathrm{ml}$. The response of drug was found to be linear regression equation $\mathrm{Y}=$ $0.0987 \mathrm{x}+0.2373$ with correlation coefficient 0.9937 (Fig. 3). All the quantitative parameters were estimated is listed in Table 1.

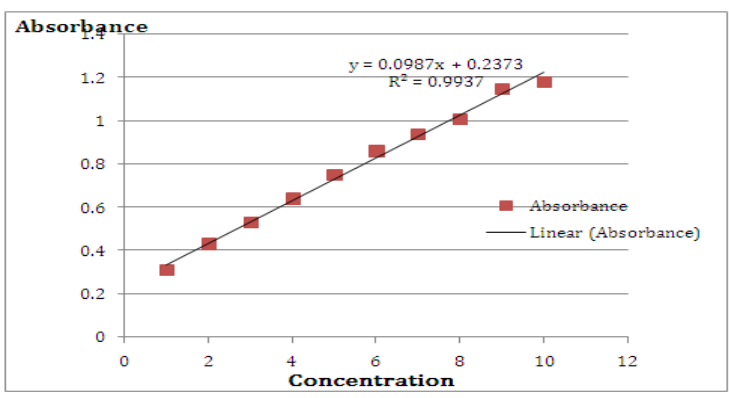

Figure 3: Calibration curve of pure AGM
Table 1: Quantitative parameters of UV spectrophotometric method

\begin{tabular}{ll}
\hline Parameter & Result \\
\hline$\lambda_{\max }(\mathrm{nm})$ & 229.6 \\
\hline Beer's law limits $(\mu \mathrm{g} / \mathrm{ml})$ & $1-10$ \\
\hline Regression equation & $\mathrm{Y}=0.0987 \mathrm{x}+0.2373$ \\
\hline Slope & 0.0987 \\
\hline Intercept & 0.2373 \\
\hline $\begin{array}{l}\text { Correlation coefficient } \\
\left(\mathrm{R}^{2}\right)\end{array}$ & 0.9937 \\
\hline
\end{tabular}

\section{Precision:}

Here, number of measurements made $[\mathrm{n}]$ are 6 . The $\%$ RSD was found to be in the range of 0.614 1.053 for intra-day precision and $0.796-1.126$ for inter-day precision (Table 2).

Table 2: Results of intra-day and inter-day precision

\begin{tabular}{lllll}
\hline $\begin{array}{l}\text { Concentration } \\
(\boldsymbol{\mu g} / \mathbf{m l})\end{array}$ & \multicolumn{2}{l}{$\begin{array}{l}\text { Intra-day } \\
\text { precision }\end{array}$} & \multicolumn{2}{l}{$\begin{array}{l}\text { Inter-day } \\
\text { precision }\end{array}$} \\
\cline { 2 - 6 } & SD & \%RSD & SD & \%RSD \\
\hline 2 & 0.022 & 0.649 & 0.033 & 0.796 \\
\hline 4 & 0.068 & 1.053 & 0.072 & 1.126 \\
\hline 6 & 0.041 & 0.614 & 0.144 & 0.873 \\
\hline $\begin{array}{l}\text { Limit of detection } \\
\text { quantification (LOQ): }\end{array}$ & (LOD) & and limit of & lim
\end{tabular}

The sensitivity of the method was assessed by determining the LOD and LOQ. The LOD and LOQ for AGM were found to be 0.577 and 1.248 $\mu \mathrm{g} / \mathrm{ml}$, respectively.

\section{Accuracy:}

Accuracy of the method was checked by the recovery studies at three different levels, i.e., 50, 100 and $150 \%$. The mean of the recovery for AGM was found to be $101.238 \%$ (Table 3).

Table 3: Results of recovery studies

\begin{tabular}{lllll}
\hline $\begin{array}{l}\text { Amount } \\
\text { of sample } \\
(\boldsymbol{\mu} \mathbf{g} / \mathbf{m l})\end{array}$ & $\begin{array}{l}\text { Amount of } \\
\text { drug added } \\
(\boldsymbol{\mu g} / \mathbf{m l})\end{array}$ & $\begin{array}{l}\text { Percent of } \\
\text { spiked } \\
\text { sample }\end{array}$ & $\begin{array}{l}\text { Amount } \\
\text { recovered } \\
(\boldsymbol{\mu g} / \mathbf{m l})\end{array}$ & $\begin{array}{l}\text { Percent } \\
\text { recovery }\end{array}$ \\
\hline 2 & 1 & $50 \%$ & 3.299 & 101.156 \\
\hline 2 & 2 & $100 \%$ & 4.320 & 101.744 \\
\hline 2 & 3 & $150 \%$ & 5.428 & 100.815 \\
\hline
\end{tabular}

\section{Robustness:}

This method was assessed by assaying test solutions under different analytical condition. For each analytical condition standard and test solutions were prepared separately. The result obtained from test solution was not affected by varying condition. 
System suitability data was found to be satisfactory during analytical conditions (Table 4).

Analytical method remains affected with slight changes but deliberately changes in the analytical conditions.

Table 4: Results of robustness studies

\begin{tabular}{lc}
\hline \multicolumn{1}{c}{ Robust conditions } & \% Assay \\
\hline Acetonitrile : Water $(75: 25, \mathrm{v} / \mathrm{v})$ & 99.75 \\
\hline Acetonitrile : Water $(50: 50, \mathrm{v} / \mathrm{v})$ & 100.37 \\
\hline Analyst change & 99.96 \\
\hline
\end{tabular}

\section{Stability of stored solutions:}

Both standard and test preparations for assay determination the solutions were stable for up to 48hrs (Table 5)

Table 5: Results of stability studies

\begin{tabular}{ccc}
\hline Intervals & $\begin{array}{c}\text { \% assay for test } \\
\text { preparation solution } \\
\text { stored at 2-8 degree } \\
\text { Celsius }\end{array}$ & $\begin{array}{c}\text { \% assay for test } \\
\text { preparation solution } \\
\text { stored at ambient } \\
\text { temperature }\end{array}$ \\
\hline Initial & 99.54 & 99.54 \\
\hline $12 \mathrm{~h}$ & 100.41 & 100.23 \\
\hline $24 \mathrm{~h}$ & 100.03 & 99.52 \\
\hline $36 \mathrm{~h}$ & 99.32 & 99.91 \\
\hline $48 \mathrm{~h}$ & 100.58 & 100.32 \\
\hline
\end{tabular}

\section{Conclusion}

The UV spectrophotometric method for estimation of AGM in bulk and pharmaceutical dosage form was successfully developed validated and. The developed method has been evaluated through specificity, linearity, robustness, accuracy, precision and stability.

\section{References}

1. Dolder CR, Nelson $M$, Snider $M$. Agomelatine treatment of major depressive disorder. Ann Pharmacother. 2008; 42(12): 1822-1831.

2. Millan MJ, Brocco M, Gobert A et al. Anxiolytic properties of agomelatine, an antidepressant with melatoninergic and serotonergic properties: role of 5-HT2 C receptor blockade. Psychopharmacology (Berl). 2005; 177(4): 448-58.

3. Firake Bhushan $M$, et al. Review on Agomelatine: A Novel Melatonergic
Antidepressant. International Journal of Advanced Research in Pharmacy and Education. 2019; 1(1): 1-8.

4. Akmar MS, Phoujdar SP.Spectrophotometric and stability indicating RP-HPLC method for quantitative estimation of agomelatine in bulk and tablet dosage form, 2014.

5. Joshi Hitendra S, RupareliyaReema $\mathrm{H}$. Stability-indicating hptlc method for quantitative estimation of agomelatine in bulk and pharmaceutical dosage form, 2(6), 2004, 5591-5601.

6. Janga KS, et al. Development of Validated RP-HPLC Method for Analysis of Agomelatine in Proliposome Powders with the Help of Central Composite Design, Kakatiya Institute of Pharmaceutical Sciences, 2006.

7. Vineela P, Pavani B, Ajitha A, Uma M V. Analytical method development and validation and stability studies of the estimation of agomelatine in tablet dosage form by RP-HPLC,4(6), 2014, 348-352.

8. Ketan KN, Ashok M, Vishwas Pukale. Validated LC-MS/MS method for quantification of agomelatine in human plasma and its application in a pharmacokinetic study, 2010.

9. Harika B, et al. Development and validation of RP-HPLC method for the estimation of agomelatine in bulk drug and pharmaceutical dosage forms. Journal of Chemical and Pharmaceutical Research, 5(12), 2013, 11621167.

10. Meghana M, Sridhar Thota, Raj Kumar V. Development and Validation of StabilityIndicating RP-HPLC Method for the Estimation of Agomelatine in API. RJPBCS 5(1), 2014, 621.

11. Shaheny R.Evaluation of agomelatine stability under different stress conditions using an HPLC method with fluorescence detection: application to the analysis of tablets and human plasma,Luminescence,29(7), 2014, 920-8.

12. Patil SR, Nerukar KK, Kalamkar AM, Pukale V, Mangaonkar KV, Pingale SG. Validated LC-MS/MS method for quantification of agomelatine in human plasma and its application in a pharmaceutical study. Journal of Mass Spectrometry, 2012; 47: 23-28. 